\title{
Influence of Negotiation Structure on the Success of Consociational Democracy in the Management of Ethno-Political Conflicts in Mandera County, Kenya
}

\author{
Joseph M.Mutungi*, David Kikaya, Anthony Ichuloi \\ Kenya \\ *Corresponding Author: Joseph M.Mutungi, Kenya

\begin{abstract}
The success of consociational democracy is dependent on the structure of negotiations leading up to its adoption and execution of the obtaining agreements. Of concern then is how the negotiations leading to consociational democracy is framed, pursued, and modified to fit in the multi-ethnic societies and the prevailing political contexts. The paper argues that negotiations occur at different levels depending on the levels of ethnic identification adopted. The paper further contends that inclusion of all significant segments, clarity of the negotiation agenda and the role of the different actors across the different layers of plural societies influence the success of consociational democracy in the management of ethno-political conflicts.
\end{abstract}

Keywords: Structure, negotiations, inclusivity, interests, positions, collaboration, actors, agenda, agreements, implementation

\section{INTRODUCTION}

The roots of democracy are traced to the city state of Athens in ancient Greece in which originally, only privileged male members of the society played a direct role in the governance of their state (Ober, 2003). This implies that women, slaves and foreigners had no role to play as far as democracy and governance were concerned in this otherwise patriarchal society. The field of political science within which the concept of consociational democracy and the practice of ethnic-based politics are situated is very rich in terms of robust debates informed by the dynamics of the human society over time.Democracy is essentially pragmatic in the sense that it allows room for change, acceptance or even discarding of things or approaches that no longer work. Thus, democracy is conceived by man for man and should at all time work for man.

The choice of approach to democracy adopted depends on an array of dynamics such as demographic composition and trends within a polity, the attendant level of political consciousness and resource availability.Human relations are expected to be harmonious especially when there is equity and inclusion in the sharing of the abundant resources as advanced by Engels and Marx in their communist thesis. The question however is whether there can be the kind of bountiful resources the duo implies so that everyone gets what they desire. The study takes the view that it is impossible because resources are finite and human nature mostly inclines people towards individualism. The ensuing disagreements based on needs, interests and values characterize the phenomenon that is conflict. The existence of conflict begets the need for actors to engage each other in an exercise ofjustifying and explaining their respective actions and therefore this spurs the possibility of a negotiation (Mwagiru, 2008).

Negotiations are a pacific approach to the management, resolution or transformation of conflicts. The deliberations that ensue in negotiations are geared towards validating and legitimizing the needs or interests of the contending parties in a conflict. Vasilev (2015) posits that negotiations build consensus which in turn enhances social learning, a central component in the management of conflicts. Lafont (2015) argues that for meaningful consensus to be build, all people that are to be affected by a given decision must be included and meaningfully participate in the process which generates the decision. Cohen (2009) is in agreement with Lafont on the need for participatory decision making, adding that the participation can be direct or through representatives. For him, a 
dialogic process entailing arguments directly made by the participants or experts on the issue in question is important in generating the necessary support for the implementation of the resultant decisions. The importance of an all-inclusive deliberation process in decision making is further stressed by Schafer (2017) who argues that the process of negotiations transforms minds and positions and if people do not participate in making a particular decision which affects them, they have no reason to accept the outcome. In essence, Shafer appears to rightly suggest that non-inclusive processes renders the decisions thereof illegitimate and hence their implementation difficult. Mansbridge (1999) further notes that the deliberations should clarify the conflict necessitating the deliberations in the first place. His proposition presents negotiations as platforms of getting to the root of conflicts so as to address them in the most effective way that leaves the society stronger.

Political processes are wrought with conflicts arising from the competitive nature of politics. In democracies, the system adopted in choosing and governing should reflect the reality of the polity because at the end of the day, democracy in general is premised on peace and stability. According to Horowitz (1993), a majoritarian system is not a viable solution in political zones whose societies are highly fragmented into ethnic-identities "because it permits domination of some groups in perpetuity" and this creates a fertile ground for conflicts to thrive. This perspective is shared by Lijphart (2012) who maintains that consensus-based democracy is 'kinder and gentler' compared to the more direct competitive and majoritarian democracy that does not take into account internal dynamics in heterogeneous societies. The centrality of dialogue in the drive towards successful political processes is further emphasized by O'Flynn (2006) who stresses the norms of reciprocity and publicity. According to O'Flynn, reciprocity appeals to reason that all parties can identify with; paving the way for mutual respect while publicity centres on open and transparent negotiation processes that focus on needs rather than positions. The concept of reciprocity builds on the legitimization of needs to the extent that parties involved in negotiations can identify with the needs of each other and regard them as important and worth being met.

\section{LITERATURE REVIEW}

To enhance the effectiveness of the structure, process and outcomes of intergroup negotiations and conflict resolution efforts, Russell,Ong, Ty and Anderson(2006), explain that it is critical that actors develop and agree on ground rules, which basically define the structure, which the negotiation processes will be anchored on. Ideally, ground rules should be among the first items that the parties to a negotiation process should establish before the actual negotiation process commences. Setting grounds rules at the earliest stages of the negotiation process is essential in expediting and facilitating the negotiation process. The ground rules should be drawn and agreed upon to ensure that they never become a hindrance or cause for delay to the process of negotiating democracy.

The findings of a study conducted by Barja, Villarroel and Zavaleta (2013) on Bolivia highlighted the significance of well-grounded policies and ground rules at the initial stages of negotiations leading up to a democratic process. The findings of the study showed that Bolivia, a plural and fragmented society, democratically suffered from its previous, poorly crafted institutional design that had not been the product of thorough discussions. In a related study that explored the negotiations leading to the coalition government following the 2007 disputed presidential elections in Kenya, Mwagiru (2008) points out the significant role played by the establishment of ground rules. The focus of such rules, the study avers, is to spell out how the negotiations would proceed including managing communication to the public.

The location of deliberations aimed at solving the differences underlying a conflict is also important. Whereas O'Flynn (2006) is in favour of elite and local levels of deliberations, Fishkin (2009) roots for the grassroot as the ideal place for deliberations. O'Flynn's proposal for the two levels of deliberations is informed by the understanding that the elite members of society have the capacity and influence over their grassroot supporters and can easily sway them as long as their private interests are camouflaged and presented as those of the community. Fishkin on his part holds the view that deliberations at the grassroots help build tolerance and trust among the masses while eliminating stereotypes and minimizing polarization. The idea of grassroot driven processes is further advocated for by Lederach (1997) who contends that a successful dialogue in handling micro issues has the potential of escalating the same to the macro level especially when the problem is symptomatic of the 
larger societal structures. Thus, civil participation in decision making regarding matters that affect the masses is important in the drive towards a sustainable outcome.

Cox and Furlong (2007), writing on the transition in Hungary following the country's experience with violent conflict in the struggle from communism to democracy posit that the roundtable discussions involving the various actors in the conflict set the country on a successful path toward democracy.This view is consistent with Stoker's (2004) assertion that there is no single actor, public or private, who has the knowledge and information required to solve complex, dynamic and diversified societal problems. Direct and indirect actors in a conflict must be involved for any envisaged peaceful outcome to bear legitimacy and support at the implementation stage. Indeed, this study takes the view that any peacebuilding effort that excludes the very people for whom the peace is being built is an exercise in futility. This line of thought is lent credence by Schuman (2006), who argues that individuals and interest groups in all sectors of society have the right to meaningful participation in the decisions that affect them.

Successful negotiations between actors translate to inclusive governance, equitable development, political stability, adherence to the rule of law, and protected property rights. Casper and Taylor (1996) maintain that democracies resulting from intense inclusive negotiation processes have a higher likelihood of succeeding and having strong consolidation while those resulting from coercive processes are likely to be weak and will eventually fail. This view is buttressed by GuoandStradiotto (2014)who emphasize that negotiations and transitions characterized by suppression of competition and refusal to relinquish elective positions are highly likely to lead to political instability.The significance of negotiations in political processes is to ensure that leadership is not monopolized by a majority or a minority of the constituent population in the political unit in question. This arrangement is important in ensuring fair sharing of the community's resources, amicable resolution of political differences, and reducing animosity within communities.

The place of the elite members of the society is of utmost importance in negotiations due to the power of control and influence they wield over the segments they identify with (Horowitz, 2014). Consequently, an actor's relative position during negotiations will also influence if one or more actors will be dominant over others, or there will be balance in order to enhance ownership of the negotiated agreements. If one or more of the actors' position is perceivably or actually weak, then the actor is likely to be easily persuaded, provided their interests are attended to. The important thing is that diversity within the negotiations provides the good will and support for outcomes. A study conducted by Adetula, Murithi and Buchanan-Clarke (2018) on the failure of peace negotiations and agreements in Africa found that good faith in negotiations is extremely important in the pursuit of agreements that will receive wide acceptance and compliance during implementation.Non-compliance in the case of South Sudan following the 2015 agreement was largely blamed on coercion in terms of sanctions threatened by the UN. The study further noted that the multiplicity of actors, each controlling a section of an armed force and claiming the support of a given ethnic group has seen a continuous metamorphosis of the conflict, as all parties seek to pursue their interests within the state's political matrix. The study by Adetula, Muriithi and Buchana-Clarke (2018) in emphasizing the significance of well-structured negotiations argues that: "...the foundations of peace and the potential for socioeconomic and political transformation depend on vital decisions made at the negotiating table, as well as the dynamics of the peace talks, including their traditionally gendered nature." Thus, plural societies must seriously address the question of goodwill among negotiators in peace negotiations, noting the influence they have in power play.

The structure of negotiated democracy should also rope in external players who are not direct beneficiaries of the negotiated democracy. Horowitz (2014) argues that external players are necessary and important for the existence of negotiated regimes.Such players act as guarantors of the agreements arrived at following the negotiations. A concurring view is held by Kerr (2006), who asserts that successful and effective consociationalism depends on external players who are considered exogenous forces.Citing an example of the Belfast Agreement which was negotiated by the US and which helped obtain a political truce between the warring factions in Northern Ireland, McGarry and O'Leary (2004) advance that external players can facilitate consociationalism by mediating or compassionately using incentives to attain mutual agreement and to abide by the powersharing institutional agreements and arrangements. 


\section{Methodology}

The study adopted a descriptive research design which allows reporting of phenomena as it naturally occurs. An embedded strategy that integrates qualitative and quantitative data was adopted with more emphasis on qualitative approaches. The inclination towards a qualitative approach was informed by low literacy levels among some key informantsas reported by KNBS (2017). The qualitative approaches were anticipated to generate in depth descriptions and explanations of phenomena under study. This was achieved by zeroing in on purposively selected key informants for in-depth interviews and Focus Group Discussions. Active politicians, elders from the various clans, women leaders, heads of households and NGOs involved in conflict management and peacebuilding formed the sampleof the study. The obtaining quantitative data was analysed using descriptive and inferential statistics while the qualitative data was analysed using thematic analysis.

\section{FINDINGS AND DISCUSSION}

In order to understand how consociational democracy is organized in Mandera County, a number of questions were developed to help generate data which is presented and discussed in this section.

\subsection{Inclusion of all Clans in the Negotiation Team}

The study sought to establish whether all clans are represented in the negotiating team and the findings are as presented in table 4.1.

Table4.1: Inclusion of All Clans in Consociational Negotiated Democracy

\begin{tabular}{|l|l|l|l|l|l|l|l|l|l|l|}
\hline & \multicolumn{2}{|c|}{ SA } & \multicolumn{2}{|c|}{ A } & \multicolumn{3}{c|}{ N } & \multicolumn{2}{c|}{ D } & \multicolumn{2}{c|}{ SD } \\
\hline & $\mathrm{F}$ & $\%$ & $\mathrm{~F}$ & $\%$ & $\mathrm{~F}$ & $\%$ & $\mathrm{~F}$ & $\%$ & $\mathrm{~F}$ & $\%$ \\
\hline $\begin{array}{l}\text { Consociational negotiated democracy } \\
\text { team comprises all clans, including } \\
\text { corner clans in Mandera County. }\end{array}$ & 9 & 3 & 15 & 5 & 21 & 7 & 93 & 31 & 163 & 54 \\
\hline
\end{tabular}

Table 4.1 shows that more than three quarters of the respondents $(85 \%)$ disagreed that the negotiation team comprised of all clans, with more than half of this dissenting group of respondents that is, 54\% strongly disagreeing. Only $8 \%$ registered agreement with the question statement as a further $7 \%$ were neutral. From the interviews and the FGDs, it was also established that historically, the Garre clan who are the majority have had a working relationship with the Murulle clan but not with the Degodia clan.

The study findings, which were unexpected because of the researcher's understanding of the significance of inclusion of significant segments in consociational processes, suggest that some of the clans did not have representatives in the negotiation team to articulate their interests. They may also mean the negotiations were spearheaded by the Garre clan, which deliberately did not want to include the Degodia clan in the county political landscape. The high disagreement rate could also be indicating that the promoters of consociational democracy did not intent that every clan is represented in the negotiations. The findings could also mean that pre-existing differences among clans are still intact and the elites are not willing to cooperate.

The subject of composition of the negotiation team is very integral to consociational democracy. The proponents of consociationalism maintain that the negotiation team must include elites from the significant segments of the polity's constitutive population for it to be successful (Lijphart, 2012). The finding that not all clans are represented in the negotiations is a strong indicator that consociationalism as conceived and practiced in Mandera County deviates from one of its cardinal tenets - inclusivity. It is this study's contention that the exclusion radicalizes elites from the marginalized clans and this serves to destabilize the polity. It is paradoxical that a process touted as a paradigm shift in the organization of politics in plural societies such as Mandera County ignores the very foundations of the practice it purports to be. The findings provide insights into the declining support for consociational negotiated democracy, especially when the 2013 and 2017 cycles are juxtaposed.

From a realpolitik perspective, the study argues that all the clans know that they cannot win any of the county seats without cooperating with at least one of the other two. Although the Garreclan is the majority in terms of population, it cannot overpower a coalition of the Murulle and the Degodia clans. 
Historically, the Garre consider the Murulle as less threatening and that they are better off being in an alliance with them. The Murulle clan on the other hand, aware of itsnumerical inferiority and the territorial claims to Mandera County made by the Garreclan has forged a working political relationship with the Garre for protection from the Degodia and to benefit politically as well.

The finding on coalition of two of the three big clans as comprising the negotiating team was corroborated by a Garre politician in an interview noted thus:

The Garre and Murulle have always had a good working relationship at least politically because the latter recognize their small numbers and if left on their own, they would not win anything. So the agreement allows the Murulleclan to take the deputy governor position and the Lafey Parliamentary Seat in addition to some appointive positions in the county government. With such a deal and the threat of losing out if the Garre worked with the Degodia (which is highly unlikely because the Degodia control Wajir County and are perceived to be intruders in Mandera by the Garre) the Murulle agree.

The respondent's assertion provides insights into the reasons why respondents who identified themselves with the Degodia clan were strongly opposed to consociational democracy. It is important to note that the inter-clan level of negotiations applies to county level positions such as the governor, deputy governor, senator and the women representative positions and some parliamentary seats.

An ANOVA test carried out to determine if at all there were differences in opinions among respondents drawn from different clans regarding inclusivity of the negotiation team in terms of the clans. The model was found not to be statistically significant in the inclusivity of clans in the negotiation team in Mandera County $\left(\mathrm{F}_{(1,300)}=.130 ; \mathrm{p}=.719>.05\right)$. A significance level of .719 implies that that there is no statistically significant difference in opinion between the clans of the respondents regarding inclusivity of the negotiation team in terms of the clans. Across the different clans represented in the survey therefore, there was a common view that the negotiation team was not inclusive in terms of the different clans living in Mandera County.

Table4.2: ANOVA for Inclusivity of Negotiation Team in Terms of clans

\begin{tabular}{|l|l|l|l|l|c|}
\hline \multicolumn{7}{|c|}{ ANOVA $^{\text {a }}$} \\
\hline & Sum of Squares & \multicolumn{1}{|c|}{ df } & Mean Square & F & Sig. \\
\hline Between Clans & .110 & 1 & .110 & .130 & .719 \\
\hline Within Clans & 110.155 & 299 & .847 & & \\
\hline Total & 110.265 & 300 & & & \\
\hline a. Dependent Variable: Inclusivity of negotiation team \\
\hline \\
b. Predictors: (Constant), Clan \\
\hline
\end{tabular}

\subsection{Composition of Negotiating Team in Terms of Gender}

Through this question, the study sought to establish whether the gender dimension was an important consideration in the formation of the negotiating teams. The study holds the view that since gender is an important factor in conflict; it should equally be taken into account in processes leading to management of the conflicts. The obtaining findings are as illustrated in Figure 4.1.

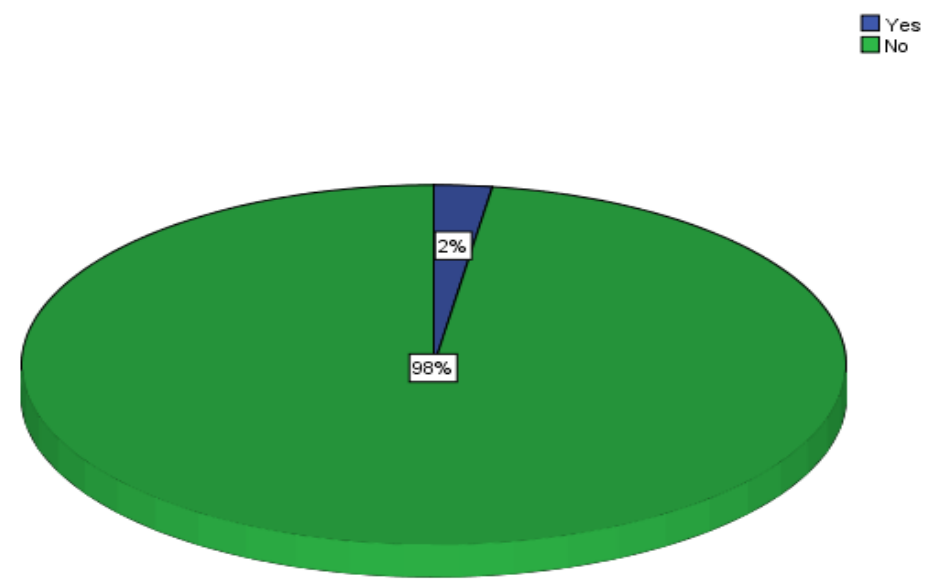

Figure4.1: Inclusion of males and females in the negotiation team 
Figure 4.1 demonstrates that an absolute majority of the respondents (98\%)believed that the negotiation team was not comprised of both men and women while $2 \%$ of the participants were of the view that the team comprised individuals drawn from both genders.

The finding implies that women are not part of the negotiations leading up to consociational democracy. This finding explains the traditional and strict observation of cultural beliefs of the Somali community and particularly the clans living in Mandera County. Women are not given opportunity to participate in any processes or activities that involve decision making on behalf of their clans. This question was brought up in an FGD held in Mandera Town and some of the responses given are presented below:

In the Somali culture, politics and generally community matters are a preserve of male elders. This has been part of our tradition because unlike women, a man will always remain to be a member of his clan. Women on the other hand can be married in other clans and they have to be loyal to their husbands' clan. They are regarded as part of the husbands' family and the children they bear are identified with the husband's clan. The Somali culture is patrilineal. Thus, women cannot be part of the team negotiating the interests of a clan. (A participant from the Male FGD)

Another response from the female only FGD held in Mandera Town noted thus:

Women are assumed to be untrustworthy in community decision making simply because some of us may have been born in one clan but married in another. Some of these traditions are unfair because they disadvantage us and deny us our voice in political decision making. We are still treated as strangers by the very people for whom we bear and raise children. (A participant from the Female FGD)

Table 4.3 captures the results of ANOVA for respondents' views on inclusivity of the negotiation team in terms of participant's sex. The model was found not to be statistically significant in the inclusion of the sexes in the negotiation team in Mandera County $\left(\mathrm{F}_{(1,300)}=1.477 ; \mathrm{p}=.226>.05\right)$. The obtaining significance value of .226 is greater than .05 . This implies that there was no statistically significant difference in opinion between the sexes of the respondents regarding inclusivity of the negotiation teams in terms of sex. This infers that respondents from across the different sexes had similar views that women were not included in the negotiation team in Mandera County.

Table4.3: ANOVA for Sex of the Respondents' and Inclusivity in Negotiation Team

\begin{tabular}{|l|l|l|l|l|l|}
\hline \multicolumn{7}{|c|}{ ANOVA $^{\text {a }}$} \\
\hline & \multicolumn{1}{|c|}{ Sum of Squares } & \multicolumn{1}{|c|}{ df } & Mean Square & F & Sig. \\
\hline Between Groups & .326 & 1 & .326 & 1.477 & .226 \\
\hline Within Groups & 28.667 & 299 & .221 & & \\
\hline Total & 28.992 & 300 & & & \\
\hline a. Dependent Variable: Inclusivity in the Negotiation Team \\
\hline \\
b. Predictors: (Constant), Sex of Respondent \\
\hline
\end{tabular}

Based on the above presentations and generally the responses emanating from the FGDs, it is clear that the male members of the Somali community in Mandera County, clan notwithstanding, are not ready to cede ground in terms of accommodating women in the negotiations. The arguments in support of excluding women are purely cultural and have nothing to do with the ability of women to make meaningful contributions during negotiations. Women on the other hand feel oppressed and denied an opportunity to actively participate in making decisions that affect their lives as envisaged in Article 174 of the CoK on the objectives of devolved governance. The younger generation particularly that has had the benefit of an education and own finances feel that women need to be included in those negotiations because they can act as bridges between clans given their loyalty on account of birth and marriage. Thus, the question of gender exclusion in decision making remains a highly contested matter which must be tackled if consociational negotiated democracy is to embody its true meaning.

\subsection{Youth Inclusion in Negotiations}

This question intended to find out the place of the youth in the negotiations as an important and active demographic in politics as expressed in the African Youth Charter (2006). The findings are as illustrated in Figure 4.2. 


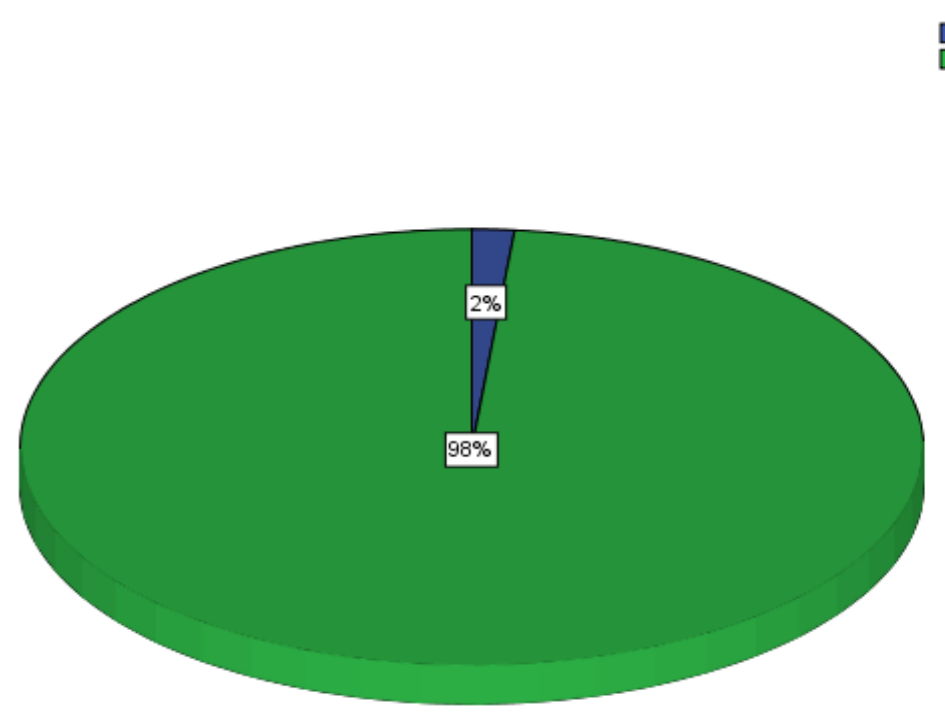

Figure4.2: Inclusion of youth in negotiation teams

From Figure 4.2, nearly all the respondents, that is $98 \%$, indicated that the youth were left out of the negotiations. Only $2 \%$ of the respondents opined that youths are included in the negotiation team.

As anticipated, the above finding implies that the youth in the county were not included in the negotiation team. The study attributed this to the stringent cultural dictates of the wider Somali community which view young people as unripe to make decisions on behalf of their clans. Youth exclusion in political decision making appears to be a problem in the wider African continent as argued by the UNDP (2012). The net effect of excluding this significant segment of the population has been their strong opposition and campaign against consociational democracy. The study notes that the youth are very energetic and versatile and tend to be easily mobilized by the anti-consociational democracy crusaders to campaign against the candidates endorsed in the negotiations and in some instances cause chaos. The import of this eventuality is prolonged or recurrence of political conflicts.

An ANOVA test was conducted between age of the respondents and their opinions on inclusion of youth in the negotiation team as shown in Table 4.4.

Table4.4: ANOVA for Age and Inclusion of Youth

\begin{tabular}{|l|l|l|l|l|l|}
\hline \multicolumn{7}{|c|}{ ANOVA $^{\text {a }}$} \\
\hline & Sum of Squares & \multicolumn{1}{|c|}{ df } & \multicolumn{1}{c|}{ Mean Square } & F & Sig. \\
\hline Between Groups & 1.735 & 1 & 1.735 & 2.059 & .154 \\
\hline Within Groups & 109.508 & 300 & .842 & & \\
\hline Total & 111.242 & 301 & & & \\
\hline a. Dependent Variable: Inclusion in negotiations \\
b. Predictors: (Constant), Age
\end{tabular}

The model was found not to be statistically significant in the inclusion of the youth in the negotiation team in Mandera County $\left(\mathrm{F}_{(1,300)}=2.059 ; \mathrm{p}=.154>.05\right)$. Results of the analysis as illustrated in Table 4.4indicate that there was no statistically significant difference in opinion between the age of the respondents and their views regarding inclusion of the youth in the negotiations. Thus, irrespective of the age of the respondents, the general view across the respondents of the different ages was that the youth were excluded from negotiation team.

\subsection{Terms of Consociational Negotiated Democracy}

The researcher sought to know the terms anchoring consociational democracy as practiced in Mandera County. One of the key terms of the process that emerged from the study was that the agreements emanating from the negotiation process must demonstrate equity in the sharing of political power and particularly elective positions. In support of this perspective, a Garre elder in an interview explained that:

The overriding interest during negotiations is to ensure participating clans get a fair share of positions being shared. 
This finding appears to imply that according to the respondent, not all clans participate in the negotiation, and this affirms an earlier finding as argued elsewhere in this paper. Equity in sharing of political power among the significant segments in the polity would help in the creation of an enabling environment in which all members can fully participate in the governance of their county. This finding resonates with Lijphart's (2012) assertion that consociationalism functions optimally under conditions of proportionality. The study however argues that the proportionality contemplated in the Mandera County consociational democracy is only limited to the clans cooperating. This deviates from the proportionality principle contemplated by the proponents of consociationalism in the sense that a coalition of two clans leaves out a significant segment that works to foster instability.

The study further established thatthere was imposition of time lines, precisely five year periods after which the stakeholders review the political governance of their polity and particularly the quality of leadership offered by those given the opportunity to lead through elections. The timelines are intentionally fixed to coincide with the general elections as provided for by the CoK. The review was intended as an opportunity for rotation of the leadership mantle among sub clans within the polity. That the review has its focus on sub-clans speaks to the complexity of the consociationalism in Mandera; it is more of a primordial intra-clan undertaking but numerical dynamics imply the stage for negotiation is moved to the clan level. The finding on the clan and intra-clan levels of engagement resonates with Lijphart's (2012) assertion that consociationalism is favored by overarching group loyalties.It further is in tandem with Woolcock's (1998) bonding and bridging typologies of social capital where the clan bridges differences among sub-clans so as to have a common position before heading to negotiations with the other clan.

In interviews with a non-governmental organization leader and an elected politician, the following responses in line with the findings were obtained:

The inclusion of leaders from across the sub-clans is very important because the leaders have some influence on whether their people accept or reject the negotiation outcomes. There is no doubt the masses will tend to align themselves with a particular individual or group of elites they think represent their interests and aspirations. (NGO Respondent)

I am a beneficiary of negotiated democracyand I can tell you for sure the system is the most ideal. Other than the rotation of leadership, the timelines given push a leader to do his best in serving the people so that he can also be considered in the future when the current term comes to an end. (Politician respondent)

Another finding of the study in respect of the terms of consociational democracy as practiced in Mandera County was that the system lets individual clans have control on matters that affect them only, including specific candidates they wish to present for election. In essence, the clans have their individual consultations among the sub-clans and consensus building on the candidate to present to the community for consideration for election as the candidate who best represents the interests of the wider clan and who can secure a win against their political opponents at the ballot or even for appointment in cases of appointive positions in the county government. The study considers this arrangement akin to one of the conditions given by Lijphart (2012) for consociational democracy to work; that segments should have exclusive control on matters specific to them. The challenge with segmental autonomy is that it tends to feed into the radical nationalist agenda and this has the potential of creating instability. This is besides accentuating group differences even when they are not that pronounced.

The study also established that for one to be considered as a negotiator he has to be an elder from his respective clan and he has to be nominated by that particular clan. Elders are communal opinion leaders, forming part of the elite within the clan. In this regard, the study noted that every clan has a team of elders who offer guidance to help the clan in taking common positions on matters germane to them. Elite decision making and interactions shape the outcomes of a regime, an argument augmented by the findings of a study conducted by Osei (2018) in Ghana. Inter-elite consultations help minimize re-entry problems after negotiations due to the influence they have over the segments they represent. The study found thatthe eliterepresenting the larger group must have unequivocal support and command respect and authority of peers who are not on the negotiation team to forestall factionalism in the community. Within the meaning of consociationalism, this study argues that there has to be 
consensus among elites from cooperating significant segments for negotiation outcomes to materialize.

The findings on terms of consociational democracy practiced in Mandera County are not in perfect harmony with those advanced by the consociational school led by Lijphart. The consultations at the sub-clan level in Mandera County prior to the inter-clan processes do not seem to feature anywhere in Lijphart's conceptualization. This could have been informed by the study's treatment of clans as ethnic groups within the larger Somali community and sub-clans as sub-ethnic groups within a clan, which is a major deviation from the understanding of ethnic groups from the state level of analysis that dominate the extant literature (Teshome-Bahiru, 2008; Horowitz, 1985). Whereas the clans are the building blocks of the Somali ethnic group, the sub-clans are the building blocks of the clan in the Somali community. The study therefore argues that consociational democracy can happen at multiple levels depending on the structure of a society (levels of differentiation and identification within a society) and the meaning of a significant segment adopted by the analyst.

\subsection{Role of Political Leaders in Consociational Democracy}

This question was intended to examine the role of political leaders in the establishment of consociational democracy in Mandera County. The findings of the study in this regard are as discussed below.

From the interviews administered it emerged that the main functions of political leaders in the establishment of consociational democracy is funding of the process and mobilization of their supporters to accept and support the decisions reached by the team of negotiators. The study established that politicians contribute the highest percentage of the negotiation process budget with the remainder being topped up by community members, especially business men. These two roles were repeated in the interviews and FGDs, with an intervieweenoting that:

Political leaders are a very important component in the realization of the success of consociational democracy because of the influence they have on their supporters. If they incite their supporters against the elders and the negotiation outcomes, implementation becomes very difficult. They also contribute their resources in funding the negotiations.

The above view was corroborated by a member of the male FGD who argued that:

Politicians influence their supporters. When they tell the supporters to do something, there is a high chance many of them will do what they are told by their political leader, whether good or bad. Their influence in the success of negotiated democracy cannot be underestimated.

These findings are in sync with those of Segawa (2015), which established that regimes emerging from ethnic based politics tend to suffer from legitimacy deficits for a variety of reasons such as marginalization of minority groups and political leaders.

The study further established that political leaders also take direct role in the negotiations by appearing before the panel of negotiators to make a case for their candidature and suitability for consideration as the flag bearer. Such engagement makes the political leaders part and parcel of the process. However, some political leaders have disagreed with the outcomes even after participating and competed outside the consociational democracy framework. In an interview with one of the key informants who vied for a parliamentary seat against the negotiated democracy candidate and won, he pointed out that:

Consociational democracy is a good idea but unfortunately, some of the negotiators are out rightly biased. They consider ones financial status more important than their leadership abilities. I disagreed with them when they invited me for discussions to build consensus on a common candidate, ran my own campaign even as they campaigned against me and I still won because my supporters believed in me and felt my competitor was being imposed on them.

This response buttresses the argument that political leaders are influential among their followers and can lead them in supporting or opposing negotiation outcomes, dealing a blow to the whole process. An FGD participant noted that by politicians directly participating in the negotiations, whether they agreed or disagreed with the outcome, that in itself gave the process some legitimacy. 
From the findings majority of the respondents were of the strong view that political leaders were crucial to the negotiation process and excluding them would cause them to sabotage the process in different ways such as withholding their financial support, marshalling their supporters to undermine the negotiation outcomes as well as denying the process the political goodwill it requires. The centrality of political leaders in consociational democracy is further lend credence by the practice of patrimonial politics in Africa (Cheeseman, 2015: Kanyinga, 2014). Mandera County is no exception to the patronage-based politics.

\subsection{Generation of Negotiations Agenda}

The researcher sought to establish the manner or process through which the agenda guiding the negotiations is generated. The findings in light of this question are as discussed below.

The study established that one of the ways through which the agenda for negotiations was obtained was by way of stakeholder consultations. The clan members as key stakeholders share their concerns, interests and views with their respective elders. At this level, the consultations are limited to the subclan level of discussions. The elders are simultaneously reaching out to political leaders, religious leaders among other cadres of leadership in the community to get their views on the concerns of the community and establish whether such concerns were reaching them in their capacity as leaders in their areas of engagement. The elders then carry with them those interests and or concerns to the clan council for fine-tuning and adoption of a common clan level agenda.

Once the agenda at the clan level has been agreed upon and firmed up, the clan elders reach out to their counterparts from other clans, share general areas of interest for discussion and subsequently plan for a meeting to harmonize the agenda. During the harmonization meeting, the elders also agree on the optimal number of negotiators to be involved, including how many from each clan. Once the agenda has been harmonized and the number of negotiators agreed, the elders set a date for the actual discussions while also reaching out to community members and politicians to mobilize resources needed to offset the negotiation process costs. An elder from the Garre clan explained the agenda generation process in an interview thus:

Everything that we do is always in the interest of the community. We consult with them on every matter. Sometimes it is the community members who approach us with their concerns. We listen to their fears and aspirations. A concerned person or group raises the issue with an elder in the sub-clan, who then considers it together with other elders and escalates it to the clan or inter-clan level if it cannot be exhausted at the lower levels.

The process of agenda generation as explained by the elder was corroborated by respondents in the FGDs and interviews with elders from the Garre and Murulle clans. The findings of this study are in sync with Lederach (1997) assertion that processes emanating from the grassroots have more ownership and hence better chances of success because of that organic nature; the people can identify with them as they participated in the process from conception.

\subsection{Progression on Discussion of Agenda Items and Consensus Building}

The researcher sought to evaluate the process through which discussions on the various agenda items progress. The findings of the study are as discussed below.

When the negotiating team meets, they discuss among themselves and agree on who will act as the chairperson and hence the team's spokesperson in its interactions with various stakeholders. The group also agrees on the ground rules as to how the discussions will proceed. In this regard, a Garre elder who participated in the key informant interviews explained the ground rules as follows:

As community leaders representing different competing interests, we have to agree on how to go about the negotiations. During the talks, we take turns to make contributions in a civil and respectful way even when we don't agree with each other's view. We also take breaks to cool off emotions and consult with opinion leaders in our respective clans on contested issues in order to ensure broad acceptance of negotiation outcomes.

After the ground rules have been set, the study established that the negotiators begin by categorizing the agenda items in terms of the most contested and complex to the seemingly easiest. In other words, 
the negotiation agenda is ranked in order to ensure adequate time and weight is given for each item. Ranking of the agenda for negotiation is an important step as it makes the process flow smoothly besides having a psychological effect on the power of agreement as argued by Elliot and Golub (2015). The actual negotiations begin with tackling the most complex and contested agenda item. Every negotiator who wishes to contribute on the agenda item is given an opportunity to make their point. The chairperson then proceeds to harmonize the emerging points of consensus and difference, keen on ironing out the differences to pave way for consensus and possibly a unanimous decision. The study further established that it is during discussions on complex agenda that emotions are at their peak as each negotiator initially sticks to their position. Members are given an opportunity to consult with their key constituents as well as any advisors they may have. It is also a moment for members to reflect on each other's propositions and possibly lobby each other for their preferred positions. A Murulle elder noted in an interview that:

Lobbying is allowed during breaks to avoid as much as possible going for a vote. We avoid the vote because it tends to destroy relations within the room. A divided leadership trickles down to the community level.

The drift towards consensus does not mean that the elders cannot take a vote on a contested matter. The study established that the preference for consensus in decision making among the negotiators who are basically elders and highly respected people in the community was intended to minimize reentry problems. Probed further on the preference for consensus, the elder explained as follows:

As elders we have a responsibility to guide our people in the direction of peaceful settlement of disputes and fair sharing of resources. If we disagree among ourselves on matters that affect us as a community, then how do we bargain for our interests with non-Somali communities? Lack of consensus among us signifies to our adversaries the existence of an opportunity for them to divide us further and rule us. (Murulle elder interviewee)

The argument presented by the elder is corroborated by Elsamann and Arafa (2012) who stressed "unanimous consensus of the community through its competent representatives" as a source of Islamic Sharia Law. Being a predominantly Muslim community, it is not surprising that religious teachings and or bases find their way in the Somali community's affairs, their clan differences notwithstanding.

Apart from the use of lobbying as a strategy for reaching consensus among the members of the negotiating team, the study established that there is the use of emissaries to convince representatives of clans to reach a common ground. The use of emissaries to obtain consensus was supported by more than half of the respondents. The study established that the emissaries are normally elders who are not part of the negotiating team and who understand the pros and cons of issues that are contested. Their work was to help negotiators understand the issues in contention from different viewpoints. Use of emissaries is a common practice in negotiations (Sebenius, 2009) aimed at altering interpersonal dynamics among negotiating parties. The emissary normally is supposed to enjoy some edge over the person they are sent to persuade and they should possess qualities similar to the negotiating parties.

As earlier noted, voting was also found to be another way of building consensus, although the least preferred approach. A religious leader who also doubles up as an elder in the community in an interview 9 explained thus:

We as Somalis and especially as Muslims strongly believe in the teachings of the Holy Quran, which encourages consensus in decision making. We dislike the vote because it brings a lot of divisions among the people. The idea of negotiated democracy borrows heavily from Islam. The voting occurring after negotiated democracy is anticipated to be a mere fulfilment of the constitution otherwise the decision taken during the negotiations should remain unchanged.

From the above discussion, it is evident that building consensus during the negotiations in the build up to the execution of consociational democracy involves lobbying and use of emissaries. The process has a lot of traction in the larger Somali community because of its close association with the Islamic faith that is prevalent in Mandera County. Voting as an approach to making a collective communal decision is avoided because of the unintended divisions that emerge therefrom. 


\subsection{Briefing of Candidates on Negotiation Outcomes}

The study sought to find out whether candidates being considered for positions from across the clans are briefed by the negotiators prior to announcement of agreements and the findings are as illustrated in Figure 4.3.

Majority of the respondents $83 \%$ agreed that candidates are briefed about the negotiations outcome prior to the announcement of agreements to the general public. About $11 \%$ of the study participants disagreedthat candidates were briefed ahead of the public declarations.

Based on these findings, it is evident that a majority of the respondents are of the view that the negotiators communicate directly to the affected persons. Communication with key stakeholders such as politicians is an important component of successful negotiations as argued by Berkovich (2006). The study established that the intention of the briefing is to consolidate the support of politicians for consociational negotiated democracy to avert escalation of tensions into violence. The move was considered essential in managing the candidates' expectations and addressing any discontentment at very early stages before going public.

In spite of this effort meant to stem re-entry problems; some of the candidates were not convinced or satisfied with the outcomes of the findings. Such candidates openly express their displeasure and proceed to vie for political seats against candidates who are fronted by the negotiating team. The study notes that even though there is a strong attempt at managing communication, fallouts happen and this greatly undermines the success of consociational democracy in managing ethno-political conflicts. The outcomes of the 2017 election cycle were a complete contrast with those of the 2013 cycle. The study attributes the fall out to the Garre elders' decision to direct all elected candidates at the time not to vie so that they give other sub-clans a chance.
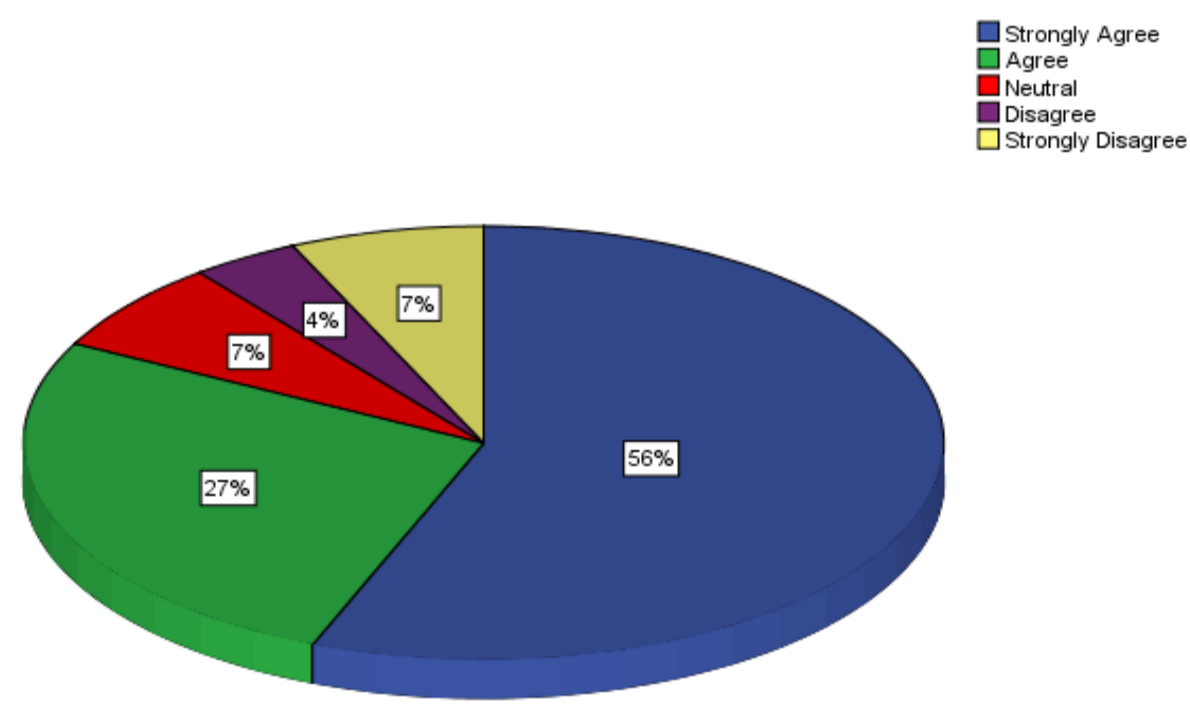

Figure4.3: Briefings of candidates about negotiation outcomes before public pronouncements of the same

\subsection{Documentation of Negotiation Proceedings}

An attempt to establish whether the negotiation team recorded the negotiation proceedings for future reference obtained the findings presented in Figure 4.4. From the figure, mmore than half of the respondents, that is 64\%, agreed that negotiation sessions and outcomes are documented as true records of proceedings. About $14 \%$ of the respondents were neutral while $15 \%$ disagreed on documentation of negotiation proceedings. $7 \%$ of the respondents expressed strong disagreement to the statement.The study findings on documentation of findings was consistent with a physical check in the clan offices in Mandera County where the researcher was shown documents emanating from negotiations, specifically in the Garre and Murulle council of elders' offices.

The study attributes the dissenting opinions on documentation to the respondents from segments that were not included in the negotiations as has been ably explored in preceding sections of this paper or respondents who simply did not know whether there was any documentation out of ignorance of the whole process. The study considered documentation important because written agreements form the 
basis for reference in the event that any of the parties claim otherwise. It also constitutes an important reference point during conflict analysis to develop alternative intervention approaches in the future as the new interveners can be properly guided on a number of issues pertinent to the conflict. This perspective tallies with the counsel given to conflict interveners by the UNDG (2016).

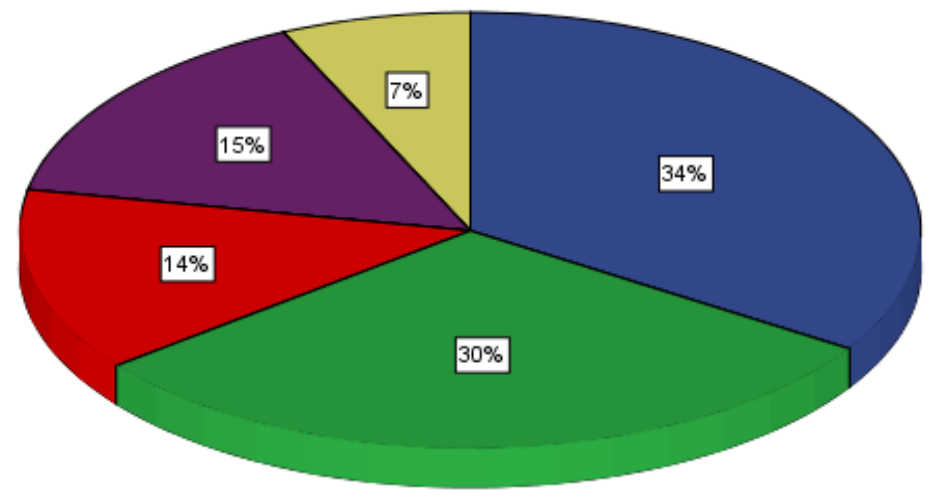

Figure4.4: Documentation of negotiation outcomes

\subsection{Challenges Encountered During Negotiations}

The study sought to establish the challenges that beset the negotiation process and the findings are as discussed hereunder and illustrated in Figure 4.5.

First, the study established that vicious attempts to financially induce negotiation team members were made to favour particular candidates. Majority of the respondents, $75 \%$ indicated that negotiators were prone to financial corruption from political entrepreneurs working at the behest of politicians. Financial corruption runs deep in Kenyan politics throughout the various stages of the political processes as argued by Kanyinga (2014). This finding further sheds light as to why most of respondents neither trust nor support consociational democracy as an avenue out of ethno-political conflicts in the county of Mandera. The findings are consistent with Lederach's (1997) caution that mistrust in negotiations militate against the success of the process. The mistrust tends to be high especially where the majority do not get fully engaged in the processes.

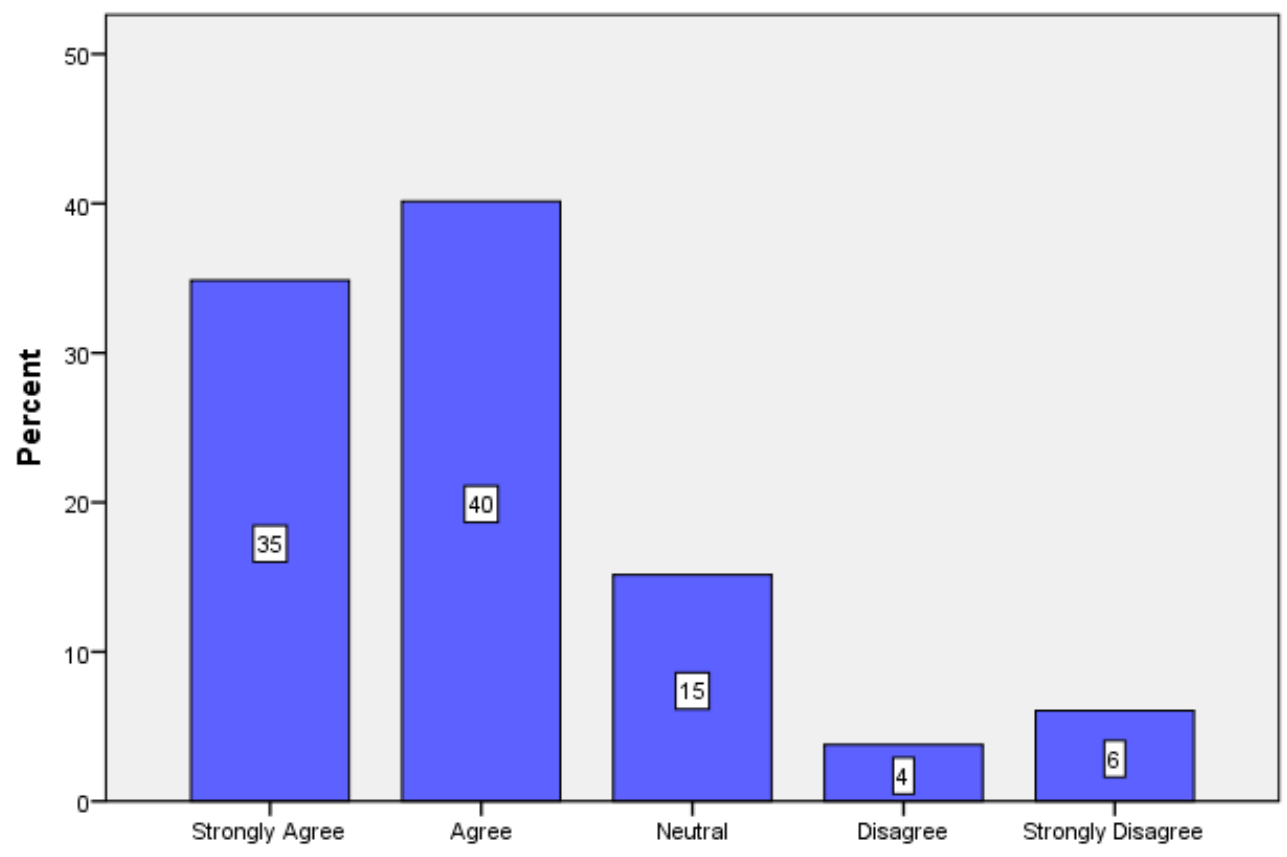

Figure4.5: Financial inducement of members of negotiating team 
Secondly, majority of the study respondents argued that parties external to the county attempted to infiltrate the negotiations to support particular candidates. This finding suggests that political processes in Mandera County generate interest from outside the polity, perhaps from state level politicians who consider the politics of Mandera County as key to the national level political arithmetic and architecture. This perspective is in sync with the findings of a study by Kanyinga (2014) that established patrimonialism as a principal pillar of politics in Kenya through the use of social networks. From the interviews conducted, it emerged that political parties operating at the national level attempted to reach out to the elders to sway them to endorse candidates from their parties with the promise of better tidings if the political party won the national elections as their candidate would act as a bridge with the national government. A participant in the male FGD decried:

Presidential candidates and their agents make attempts to influence the elders through emissaries to support particular candidates who they think is a pillar to their national political programming, irrespective of whether he is popular at the grassroots.

The import of such infiltration attempts would mean that if successful, the interests of the communities would be subservient to those of the infiltrating party, effectively undermining the entire logic of consociational democracy and its attendant peace package as advanced by its proponents.

Thirdly, the study found that intra-clan rivalries affected the choice of candidates proposed to various offices as indicated bymajority of the respondents (75\%). The study is cognizant of the fact that clans are constituted by sub-clans whose influence cannot be underestimated particularly in a process that involves politics whose key defining feature is numbers. The study argues that for the intra-clan rivalries to be contained so that they do not undermine consociational negotiated democracy and its contribution to ethno-political conflict management, there is need by clan leadership to consult extensively across sub-clans and elders to be more open with information so that they are not perceived as side-lining certain sub clans. Intra-group rivalries are fuelled by perceptions that only a member of the immediate family or sub-clan can guarantee his people their rightful share. Mistrusts which undermine negotiations increase as the group grows and particular limited resources are being pursued.

Finally, the study established that the negotiation team was entirely comprised of elders who were not necessarily experts with the skill set in alternative dispute resolution. Majority of the respondents, $67 \%$, strongly agreed that involvement of independent expert does influence the strength of the agreements reached between negotiating parties.Expert knowledge and skill set is a crucial component in negotiations as the holders are able to undertake a thorough analysis of the conflict and direct interventions towards addressing the root causes of the inter-ethnic violence. The significance of expert advice in negotiations is highlighted by Mwagiru (2008) who credited the success of the Koffi Annan-led negotiation team to the efforts and advice of the backroom advisors who helped with the negotiations, suggesting potential strengths and pitfalls to positions advocated by parties in the negotiations.

\section{CONCLUSION}

The kind of negotiated democracy practiced in Mandera County does not entirely conform to the pillars of consociationalism, particularly with regard to inclusion of all segments of the county population. Exclusion of the Degodia clan, women and youth undermines the process ab initio.The teachings of the Islamic faith on justice and fairness were found to have been instrumental in decision making during negotiations. The significance of political leaders in the realization of consociational democracy was informed by the power and influence they wielded with regard to their constituents. Their funding the negotiations, provision of goodwill to the practice and mobilization of supporters to accept decisions even when the decisions did not favour them and presentation of opinions of their followers underscored their indispensability. The cross-cutting consultations, both vertical and horizontal in the agenda generation as well as its fractionation in terms of complexity positively impacts on the success or failure of the negotiations leading up to consociational democracy. The study finding that negotiations aimed at consociationalism occurred at two levels; the sub-clan and the clan level was very significant in enriching the extant literature whose focus of ethnicity has been only at the national level, ignoring complex kinship dynamics especially in Africa. 
Influence of Negotiation Structure on the Success of Consociational Democracy in the Management of Ethno-Political Conflicts in Mandera County, Kenya

\section{REFERENCES}

[1] Adetula, V., Murithi, T., \& Buchanan-Clarke, S (2018), Peace Negotiations and Agreements in Africa Why They Fail and How to Improve Them NAI Policy Note No 8

[2] AU (2006) African Youth Charter accessed on $14^{\text {th }}$ May 2019 at https://au.int/en/treaties/african-youthcharter

[3] Barja, G.,Villarroel, S.\&Zavaleta, D.(2013) Institutional design and implicit incentives in Bolivia's decentralization model, MPRA Paper 66050, University Library of Munich, Germany

[4] Bercovitch, J. (2006) Is There Method in the Madness of Mediation? Some Lessons for Mediators from Quantitative Studies of Mediation International Interactions Vol. 32 (4): 329-354

[5] Casper, G \& Taylor, M. (1996) Negotiating Democracy: Transitions from Authoritarian RuleUniversity of Pittsburgh Press

[6] Cheeseman, N. (2015), Democracy in Africa: Successes, failures, and the struggle for political reform, Cambridge: Cambridge University Press.

[7] Cohen, J. (2009) Reflections on Deliberative Democracy in T.Christiano and J.Christman (Eds.), Contemporary Debates in Political Philosophy, pp. 247-263. Oxford: Wiley- Blackwell.

[8] Cox, T. \& Furlong, A. (2007) Political transition in Hungary: An overviewJournal of Communist Studies and Transition Politics, Vol. 10(3), pp.1-12.

[9] Elliott, M. \& Golub, B (2015) Ranking Agendas for Negotiations accessed on $14^{\text {th }}$ May 2019 at http://www.bengolub.net/papers/agendas.pdf

[10] Elsaman, R.S. and Arafa, M.A. (2012) The Rights of the Elderly in the arab Middle East: Islamic Theory versus Arabic Practice Marquette Elders advisor Vol. 14 (1) Article 4

[11] Fishkin, J. S. (2009) When the People Speak. Oxford: Oxford University Press.

[12] Guo, S. \& Stradiotto, G. A., (2014). Democratic Transitions: Modes and Outcomes. London: Routledge

[13] Horowitz, D. (1985). Ethnic Groups in Conflict, Los Angeles: University of California

[14] Horowitz, D.L (2014) Ethnic Power Sharing: Three Big Problems Journal of DemocracyVol. 25 (2):5-20.

[15] Horowitz, D.L. (1993) Democracy in Divided Societies Journal of Democracy 4(4): 18-38.

[16] Kanyinga, K. (2014) Kenya: Democracy and Political Participation Discussion Paper, OSIEA

[17] Kerr, M. (2006) Imposing Power-Sharing: Conflict and Coexistence in Northern Ireland and Lebanon, Dublin: Irish Academic Press

[18] KNBS, (2017) Exploring Kenya's inequality: Pulling apart or pulling together? Nairobi

[19] Lafont, C. (2015). Deliberation, Participation and Democratic Legitimacy: Should Deliberative Mini- Publics Shape Public Policy? Journal of Political Philosophy Vol. 23(1): 40-63.

[20] Lederach, J.P. (1997) Building Peace: Sustainable Reconciliation in Divided Societies Washington DC: United States Institute of Peace

[21] Lijphart, A. (2012).Patterns of democracy New Haven: Yale University Press

[22] Mansbridge, J. (1999). Everyday Talk in the Deliberative System in S.Macedo (Ed.), Deliberative Politics: Essays on Democracy and Disagreement, pp. 211-239. New York and Oxford: Oxford University Press.

[23] McGarry, J. \& O'Leary, B., (2004)The Northern Ireland Conflict: Consociational Engagements. Oxford: Oxford University Press.

[24] Mwagiru, M. (2008).The Water's Edge: Mediation of Violent Electoral Conflict in Kenya, Nairobi: IDIS

[25] O’Flynn, I. (2006) Deliberative Democracy and Divided Societies Edinburgh: Edinburgh University Press

[26] Ober, J (2003) Conditions for Athenian Democracy in Rabb and Suleiman (Eds.)The Making and Unmaking of Democracy: Lessons from History and World Politics, Routledge: London

[27] Osei, A. (2018) Elite Theory and Political Transitions: Networks of Power in Ghana and Togo, Comparative Politics 51(1):21-42

[28] Russell, S., Ong, L.D., Ty, R. \&Anderson A.G (2006) Inter-Ethnic Dialogue and Conflict Resolution in Southern Philippines: Access to Community and Civic EnrichmentIllinois: Northern Illinois University

[29] Schäfer, A. (2017) Deliberation in Representative Institutions: An Analytical Framework for a Systemic Approach Australian Journal of Political Science, Vol. 52(3): 1-17.

[30] Schuman, S. P. (2006) Creating a Culture of Collaboration: International Association of Facilitators' Handbook. San Francisco: Jossey-Bass

[31] Sebenius, J.K. (2009) Negotiation analysis: From Games to Inferences to Decisions to Deals Negotiation Journal Vol. 25 (4): 449-465 
Influence of Negotiation Structure on the Success of Consociational Democracy in the Management of Ethno-Political Conflicts in Mandera County, Kenya

[32] Segawa, N. (2015) Ethnic Politics and Consociationalism in the 2013 Malaysian Election Japanese Journal of Political Science 16(2): 177-194.

[33] Stoker, G. (2004) New Localism, Progressive Politics and Democracy The Political Quarterly Vol. 75 (1): 117-129

[34] Teshome-Bahiru, W., (2008). Ethnicity and Political Parties in Africa: The Case of Ethnic-Based Parties in Ethiopia. Journal of International Social Research, 1(5):780-809 Available at SSRN: https://ssrn.com/ abstract $=1305112$ /

[35] UNDG (2016) Conducting a Conflict and Development Analysis accessed on $20^{\text {th }}$ May 2019 available at https://undg.org/wp-content/uploads/2016/10/UNDP_CDA-Report_v1.3-final-opt-low.pdf

[36] UNDP (2012) Enhancing Youth Political Participation throughout the Electoral Cycle - A good practice guide accessed on $14^{\text {th }}$ May 2019 at https://www.undp.org/content/undp/en/home/librarypage/democraticgovernance/electoral_systemsandprocesses/enhancing-youth-political-participation-throughout-theelectoral/

[37] Vasilev, G. (2015). The Uneasy Alliance between Consensus and Democracy The Review of Politics, Vol. 77(1):73-98

[38] Woolcock, M. (1998) Social Capital and Economic Development: Toward a Theoretical Synthesis and Policy Framework Theory and Society 27(2):151-208.

Citation: Joseph M.Mutungi, et.al. "Influence of Negotiation Structure on the Success of Consociational Democracy in the Management of Ethno-Political Conflicts in Mandera County, Kenya". International Journal of Humanities Social Sciences and Education (IJHSSE), vol. 6, no.9, 2019, pp. 43-58. doi: http://dx. doi.org/10.20431/2349-0381.0609005.

Copyright: (C) 2019 Authors. This is an open-access article distributed under the terms of the Creative Commons Attribution License, which permits unrestricted use, distribution, and reproduction in any medium, provided the original author and source are credited. 